\title{
KARAKTERISTIK PENDIDIKAN KARAKTER; MENJAWAB TANTANGAN MULTIDIMENSIONAL MELALUI IMPLEMENTASI KURIKULUM 2013
}

\author{
Syaiful Islam \\ Institut Agama Islam Nurul Jadid Paiton Probolinggo \\ Email : syaifulislam182@gmail.com
}

\section{Abstract;}

Pelaksanaan pendidikan karakter di lingkungan pendidikan formal memiliki Pengaruh yang efektif dalam mengatasi fenomena anarkisme, pengenaan kehendak, perkelahian Pelajar, proliferasi pengedar narkoba dan pengguna, krisis lingkungan, krisis moral, dan Berbagai kecenderungan sosial lainnya. Pendidikan formal adalah sistem pendidikan yang terorganisir, terarah, dan terukur. Kurikulum 2013 mengorientasikan dan menekankan pada Penguatan nilai moral, afektif, dan nilai konsep KI-1 (sikap spiritual), KI-2 (Sikap sosial), KI-3 (pengetahuan), dan KI-4 (penerapan pengetahuan). Implementasi dari Pendidikan karakter dalam Kurikulum tahun 2013 dapat dikembangkan dengan mengintegrasikan kognitif, Afektif, dan aspek psikomotor. Selain itu, untuk mendorong dan memfasilitasi realisasi Sinergi antara pendidikan formal, nonformal dan informal, dan mendorong untuk Terus meningkatkan kompetensi dan model peran para pendidik untuk mengimplementasikan Kurikulum 2013.

Keywords; curriculum, Islamic education, educational character 


\section{Pendahuluan}

Tidak dapat dipungkiri bahwasannya pendidikan membawa pengaruh besar terhadap peningkatan kualitas dan perilaku hidup masyarakat karena pendidikan merupakan media transformasi kepribadian dan pengembangan diri seseorang. Oleh karena itu, diperlukan pendidikan dengan proses pembelajaran yang bermutu dalam rangka mewujudkan tujuan pendidikan. Pendidikan dapat dikategorikan bermutu bila memiliki forward linkage dan backward linkage. Forward linkage yaitu pendidikan bermutu yang merupakan syarat utama untuk mewujudkan kehidupan bangsa yang maju, adil dan sejahtera. Ada begitu banyak pelajaran yang dapat dipetik dari sejarah perkembangan serta kemajuan bangsa yang modern dan sejahtera, yaitu sistematika dan regulasi penddiikan yang bermutu (Sukmadinata, 2010: 27).

Pendidikan karakter merupakan salah satu upaya mendasar dalam menciptakan situasi belajar yang memenuhi kebutuhan pengembangan diri siswa pada interaksi belajar yang dirancang guna membentuk siswa berkarakter. Meskipun pembentukan dan pengembangan karakter dapat dilakukan di rumah melalui bimbingan orang tua dan lingkungan sekitar. Namun, sekolah juga memiliki peran penting dalam pembentukan karakter siswa (Suyadi, 2013: 3). Dengan harapan, bahwasannya melalui pendidikan karakter akan menjadikan siswa sebagai sosok yang bertaqwa kepada Tuhan Yang Maha Esa, memiliki keimanan yang kuat sehingga melahirkan pribadi yang berbudi luhur, toleran terhadap sesama, memiliki motivasi juang dan mempu bekerja keras, berprestasi dan disiplin, sikap menghargai orang lain dan demokratis, bertanggungjawab, kreatif dan mandiri (Majid, 2011: 11). Tidak dapat dipungkiri, pendidikan karakter yang mulai ditanamkan melalui proses pembelajaran di sekolah memiliki andil yang sangat besar dan esensial sebagai bagian dalam proses pembentukan akhlak.

Agar dapat mengikuti perkembangan zaman, sebuah sistem pendidikan harus memiliki kurikulum yang bersifat dinamis serta mengalami perubahan yang sistematis dan pengembangan yang berkelanjutan dan terarah (Syarif, 2004: 17). Selain sebagai bentuk penyesuaian akan kebutuhan pendidikan yang terus berkembang, Perubahan kurikulum diperlukan karena ditemukannya beberapa kelemahan pada implementasi 
kurikulum sebelumnya. Pada kurikulum yang diberlakukan pada periode sebelumnya, yaitu Kurikulum Tingkat Satuan Pendidikan (KTSP) di tahun 2006 yang memiliki kecenderungan bermuara pada aspek pengetahuan saja meski terdapat aspek psikomotor dan afektif didalamnya. Namun, hal itu tidaklah cukup untuk menghantar peserta didik menjadi generasi berkarakter dalam sebuah sistem pendidikan yang baik (Mulyasa, 2013: 61).

\section{Etimologi Karakterisitik Karakter}

Dalam bahasa Yunani, Karakter (charasseim), berarti "mengukir" atau "dipahat" (Kesuma, 2011: 11). Beberapa tokoh pendidikan berpendapat bahwa karakter merupakan manifestasi perilaku seseorang, seperti jujur, kejam, rajin dan lain sebagainya. Selain itu, karakter juga berkaitan erat dengan personalitas seseorang. Hal itu menunjukkan bahwa karakter merupakan nilai dari bentuk perilaku. Hanya saja nilai-nilai yang terkandung di dalam perilaku seseorang bersifat relatif, sehingga nilai dari suatu perilaku sangat sulit dipahami oleh orang lain (Megawangi, 2007: 9). Kualitas dan kekuatan mental atau moral, akhlak atau budi pekerti merupakan kepribadian khusus yang menjadi pendorong atau penggerak, serta pembeda satu individu dengan individu lainnya juga merupakan bagian dari karakter. Dengan demikian, seseorang dapat dikatakan berkarakter jika telah berhasil menyerap nilai-nilai dan keyakinan yang dikehendaki oleh masyarakat serta digunakan sebagai kekuatan moral dalam hidupnya.

Manusia sebagai makhluk yang diciptakan dengan potensi akal sebagai kemampuan yang tidak dimiliki oleh makhluk lainnya memiliki kewajiban untuk terus mengembangkan kapabilitas tersebut dan menjadi sosok yang mampu mengemban tugas dalam memelihara alam ini, sebagaimana firman Allah SWT dalam surat Al Baqarah yang artinya "...dan ingatlah ketika Tuhanmu berfirman kepada para Malaikat, "sesungguhnya aku hendak menjadikan khalifah dimuka bumi" Mereka berkata "Apakah Engkau hendak menjadikan orang yang merusak dan menumpahkan darah dimuka bumi sedangkan kami bertasbih, memujiMu dan menyucikan namaMu?" Dia berfirman "Sesungguhnya Aku mengetahui apa yang tidak kamu ketahui". Selain 
itu, tujuan diciptakannya manusia adalah untuk mengabdi dan beribadah kepada Allah selaku Dzat yang telah menciptakan manusia dan alam beserta isi, sebagaimana firmanNya (Q.S. 2: 30)". Agar tujuan diciptakannya manusia sebagai makhluk paling mulia di sisiNya, maka pengembangan karakter dalam diri manusia perlu terus terpelihara agar terbentuk sifat maupun perilaku yang baik dan terpuji.

Demikian pula dengan pembentukan karakter seseorang dalam dunia pendidikan, terutama dalam dunia pendidikan Islam. Pendidikan karakter dalam pendidikan Islam lebih menekankan pada pengembangan individu melalui penanaman akhlak terpuji sehingga mampu menjadikan dirinya sebagai individu yang baik bagi pribadi, orang disekitarnya dan masyarakat luas. Hubungan pribadi dengan masyarakat dalam Islam, diikat oleh budaya di lingkungan masyarakat yang kemudian disebut norma kemasyarakatan atau lebih dikenal dengan 'ilqah rūhiyyah khuluqiyah' (interaksi yang diikat oleh kode etik).

Oleh karena itu, siswa sebagai bagian dari kelompok kecil dalam masyarakat merupakan penerus tongkat estafet tradisi budaya masyarakat nantinya yang harus terus dibina guna menumbuhkembangkan karakater beradab. Adapun pendekatan yang dapat dilakukan guna merealisasikan tujuan tersebut di atas adalah (Hasan, 1985:32);

1. Keteladanan

Keteladanan merupakan sebuah sikap dan perilaku yang muncul dari hati, sehingga apa yang dilakukan tidak menyimpang dari kehendak Tuhan dan norma kemasyarakatan (Hidayatullah, 2010: 39).

2. Penanaman Disiplin

Kedisiplinan adalah ketaatan yang didukung oleh kesadaran guna menunaikan tugas dan kewajiban serta berperilaku sesuai aturan atau tatanan yang berlaku dalam suatu lingkungan tertentu (Muslich, 2011: 172). Melaksanakan aturan dan kaidah-kaidah yang ada dengan kedisiplinan memiliki nilai yang dapat dijadikan tolok ukur kepribadian seseorang. Hal ini merupakan usaha dalam membentuk pribadi yang berkarakater.

3. Pembiasaan 
Tumbuh kembang seseorang dibentuk oleh lingkungan sekitarnya. Lingkungan memiliki peran besar dalam pembentukan karakter seseorang akibat dari pembiasaan yang dihadapinya tiap saat (Wibowo, 2013:7). Oleh karena itu, tugas pribadi-pribadi di sekitarnya untuk menjadikan lingkungan sebagai media pembelajaran yang baik dalam rangka membentuk dan mengembangkan potensi seseorang menjadi individu yang baik.

4. Menciptakan Suasana Kondusif

Perilaku kondusif dari lingkungan juga turut berperan dalam pembentukan karakter seseorang, semakin baik atmosfir lingkungan tersebut, maka semakin baik pula karakter yang terbentuk.

\section{Rekonstruksi Karakteristik Karakter}

Karakter merupakan sifat dasar yang dimiliki oleh seseorang. Bukan berarti karakter seseorang tidak bisa berubah dan dibentuk hingga menjadi sosok yang semakin baik. Dalam perkembangannya, ada 2 faktor yang mempengaruhi terbentuknya karakter seseorang, yaitu (Megawangi, 2007:33);

1. Faktor Intern (Endogen)

Anak terlahir dalam kondisi belum mampu mengelola keinginankeinginannya sendiri. Pembentukan karakter dapat dilakukan di usia dini anak. Penanaman sifat, sikap dan tatanan sosial seorang anak tergantung dari motivasi yang diberikan orang tua, orang-orang disekitarnya dan lingkungan. Disamping itu, anak juga memiliki sifat yang mengalir dalam dirinya melalui bawaan sifat orang tua.

2. Faktor Eksogen/Nature (Faktor Lingkungan)

Manusia terlahir ke dunia hanya dibekali dengan sifat bawaan, baik berupa nilai-nilai ketaqwaan (kebaikan) dan kemungkaran (kejelekan). Dari kedua hal tersebut, masih sangat memungkinkan adanya potensi pengembangan dan perubahan melalui pelbagai pengaruh (Megawangi, 2007: 60),

a. Dimensi Pendidikan 
Pada surat Al Luqman ayat 13 - 14 menggambarkan bagaimana pelaksanaan pembelajaran dan pendidikan dalam keluarga, keutamaan akan pendidikan ketuhanan dan keimanan jelas terurai dalam ayat tersebut. Begitu pentingnya pendidikan keagamaan, ketuhanan dan keimanan karena dari aspek tersebut memuat pondasi utama dari pembentukan karakter.

b. Dimensi Sosial

Selain dimensi pendidikan, dimensi sosial juga memiliki peran penting dalam pembentukan karakter anak, baik dalam lingkungan keluarga, sekolah dan masyarakat.

a) Lingkungan Sosial dalam Keluarga

Lingkungan keluarga merupakan lingkungan terdekat dalam proses tumbuh kembangnya anak. Lingkungan ini memiliki peran paling besar dalam pembentukan karakter seseorang, terutama lingkungan sosial anak. Fungsi utama keluarga seperti yang diuraikan dalam resolusi majelis umum PBB adalah sebagai wahana untuk mendidik, mengasuh dan mensosialisasikan anak, mengembangkan kemampuan seluruh anggotanya agar dapat menjalankan fungsinya di masyarakat dengan baik serta memberikan kepuasan dan lingkungan yang sehat guna tercapainya keluarga yang sejahtera.

b) Lingkungan Sosial Sekolah

Dalam membentuk dan membangun karakter anak, peran interaksi sosial dalam keluarga sangat besar. Akan tetapi, sebagian besar kehidupan anak yang berstatus pelajar menghabiskan waktu dan bersosialisasi di sekolah. Sekolah merupakan tempat yang paling tepat dalam rangkaian pembentukan pendidikan karakter anak.

Pendidikan karakter bukan pendidikan yang mengajarkan aspek kognisi tentang pilihan baik maupun buruk (Haryanto, 2012: 52). Pendidikan karakter merupakan internalisasi nilai-nilai positif melalui proses pembelajaran yang baik dan benar (Kesuma, 2011: 20). 
Pemerintah telah mengidentifikasi 18 nilai-nilai yang mengindikasikan karakter yang bersumber dari agama, budaya, sosial dan falsafah kabangsaan guna memperkokoh pelaksanaan pendidikan karakter, yaitu (Syarbini, 2012: 25 - 28):

a. Religius

Nilai religius adalah prilaku patuh dalam melaksanakan ajaran agama, sikap toleran atas pelaksanaan ibadah agama lain dan menjaga kerukunan antar pemeluk agama/kepercayaan lain

b. Jujur

Nilai jujur adalah sikap berdasar pada usaha menjadi orang yang perkataan, sikap dan tingkah lakunya terpercaya

c. Toleransi

Nilai dalam toleransi adalah sikap dan tindakan yang menghargai perbedaan agama, suku, etnis, pendapat, sikap dan tindakan orang lain yang berbeda dari dirinya.

d. Disiplin

Nilai disiplin adalah tindakan yang menunjukan perilaku tertib dan patuh pada berbagai ketentuan dan peraturan

e. Kerja Keras

Nilai dalam kerja keras adalah perilaku yang menunjukkan upaya sungguh-sungguh dalam mengatasi berbagai hambatan belajar dan tugas, serta menyelesaikan tugas dengan sebaik-baiknya.

f. Kreatif

Nilai kreatif adalah berfikir dan melakukan sesuatu untuk menghasilkan cara atau hasil baru dari sesuatu yang telah dimiliki.

g. Mandiri

Nilai mandiri adalah sikap dan perilaku yang tidak mudah tergantung pada orang lain dalam menyelesaikan tugas.

h. Demokratis

Nilai demokratis adalah cara berfikir, bersikap dan bertindak yang menilai sama hak dan kewajiban dirinya dan orang lain. 
i. Rasa Ingin Tahu

Nilai rasa ingin tahu adalah sikap dan tindakan yang selalu berupaya untuk mengetahui lebih mendalam dan meluas dari sesuatu yang dipelajarinya, dilihat dan didengar.

j. Semangat Kebangsaan

Nilai semangat kebangsaan adalah cara berfikir, bertindak dan berwawasan yang menempatkan kepentingan bangsa dan negara di atas kepentingan bangsa dan negara di atas kepentingan diri dan kelompoknya.

k. Cinta Tanah Air

Nilai cinta tanah air adalah cara berfikir, bertindak dan berbuat yang menunjukkan kesetiaan, kepedulian dan penghargaan yang tinggi terhadap bangsa, lingkungan fisik, sosial budaya, ekonomi dan politik bangsa.

I. Menghargai Prestasi

Nilai menghargai prestasi adalah sikap dan tindakan yang mendorong dirinya untuk menhasilkan sesuatu yang berguna bagi masyarakat dan mengakui serta menghormati keberhasilan orang lain.

m. Bersahabat/Komunikatif

Nilai bersahabat/komunikatif adalah indakan yang memperlihatkan rasa senang berbicara, bergaul dan bekerja sama dengan orang lain

n. Cinta Damai

Nilai cinta damai adalah sikap, perkataan dan tindakan yang menyebabkan orang lain merasa senag dan aman atas kehadiran dirinya.

o. Gemar Membaca

Nilai gemar membaca adalah kebiasaan menyediakan waktu untuk membaca berbagai bacaan yang memberikan kebajikan bagi dirinya.

p. Peduli Lingkungan

Nilai peduli lingkungan adalah sikap dan tindakan yang selalu berupaya mencegah kerusakan pada lingkungan alam di sektarnya dan mengembangkan upaya-upaya untuk memperbaiki kerusakan alam yang sudah terjadi. 
q. Peduli Sosial

Nilai peduli sosial adalah sikap dan tindakan yang selalu ingin memberi bantuan kepada orang lain dan masyarakat yang membutuhkan.

r. Tanggung Jawab

Nilai tanggung jawab adalah sikap dan perilaku seseorang untuk melaksanakan tugas dan kewajibannya untuk seharusnya dia lakukan terhadap diri sendiri, masyarakat, lingkungan negara dan Tuhan Yang Maha Esa.

Dari uraian di atas jelas bahwa kesamaan motif yang didasarkan pada kesamaan kebutuhan, menyebabkan orang-orang menghimpun diri dan bekerjasama di dalam suatu wadah yang disebut dengan lembaga atau institusi, keadaan seperti itu berlangsung juga dalam bidang pendidikan, sehingga dapat dikatakan bahwa pendidikan diluar lingkungan keluarga sebagai suatu kebutuhan bersama, harus dilaksanakan secara teratur, dan terarah.

\section{Dinamika Kurikulum Indonesia}

Kurikulum dapat dipandang sebagai buku atau dokumen yang digunakan guru sebagai pegangan dalam proses belajar mengajar. Kurikulum dapat juga dilihat sebagai produauk yaitu apa yang diharapkan dapat dicapai siswa dan bagaimana proses mencapainya. Kurikulum dapat juga diartikan sebagai sesuatu yang hidup dan berlaku selama jangka waktu tertentu dan perlu direvisi secara berkala agar tetap relevan dengan perkembangan zaman. Meski terdapat beberapa perbedaan atas definisinya, kurikulum tetaplah kurikulum yang menjadi perangkat untuk mencapai tujuan.

Adapun fungsi kurikulum dalam pendidikan tidak lain merupakan alat untuk mencapai tujuan pendididkan. Dalam hal ini, alat untuk menempa manusia yang diharapkan sesuai dengan tujuan yang diharapkan. Pendidikan suatu bangsa dengan bangsa lain tidak akan sama karena setiap bangsa dan negara mempunyai filsafat dan tujuan pendidikan tertentu yang dipengaruhi oleh berbagai segi, baik segi agama, idiologi, kebudayaan, maupun kebutuhan negara itu sendiri. 
Pemerintah sebagai pemangku kebijakan sistem pendidikan di Indonesia, memiliki hak penuh guna menyusun dan mengelola pengembangan perangkat yang digunakan untuk mencapai tujuan pendidikan nasional yang telah ditetapkan. Melalui sistem pendidikan yang disesuaikan dengan tuntutan global, pemerintah dengan BNSPnya berupaya membangun sebuah sistem pendidikan yang dikelola guna memenuhi kebutuhan tersebut tanpa mengesampingkan nilai kepribadian dan moralitas anak bangsa yang beradab, diharapkan mampu membawa manusia Indonesia ke arah yang lebih baik.

Undang-undang No. 20 Tahun 2013 tentang Sistem Pendidikan Nasional dalam pasal 1 Butir 9 UUSPN menyatakan bahwa kurikulum adalah seperangkat rencana dan pengaturan mengenai isi dan bahan pelajaran serta cara yang digunakan sebagai pedoman penyelenggaraan kegiatan belajar mengajar. Rumusan tentang kurikulum ini mengandung makna bahwa kurikulum meliputi rencana, isi, dan bahan pelajaran dan cara penyelenggaraan kegiatan belajar mengajar (Prihatin, 2008: 61).

Sejak diberlakukan pada tahun 2006 lalu, sebagian pemerhati pendidikan di Indonesia menilai ada beberapa permasalahan yang terjadi seputar Kurikulum Tingkat Satuan Pendidikan (KTSP). Adapun permasalah tersebut di antaranya (Mulyasa, 2013: 64);

a. Konten kurikulum yang masih terlalu padat, ini ditunjukkan dengan banyaknya mata pelajaran dan banyak materi yang keluasan dan tingkat kesukarannya melampaui tingkat perkembangan usia anak.

b. Belum sepenuhnya berbasis kompetensi sesuai dengan tuntutan fungsi dan tujuan pendidikan nasional.

c. Kompetensi belum menggambarkan secara holistik domain sikap, keterampilan, dan pengetahuan; beberapa kompetensi yang dibutuhkan sesuai dengan perkembangan kebutuhan (misalnya pendidikan karakter, metodologi pembelajaran aktif, keseimbangan soft skills dan hard skills, kewirausahaan) belum terakomodasi di dalam kurikulum.

d. Belum peka dan tanggap terhadap perubahan sosial yang terjadi pada tingkat lokal, nasional, maupun global. 
e. Standar proses pembelajaran belum menggambarkan urutan pembelajaran yang rinci sehingga membuka peluang penafsiran yang beraneka ragam dan berujung pada pembelajaran yang berpusat pada guru.

f. Standar penilaian belum mengarahkan pada penilaian berbasis kompetensi (proses dan hasil) dan belum secara tegas menuntut adanya remediasi secara berkala; dan

g. KTSP memerlukan dokumen kurikulum yang lebih rinci agar tidak menimbulkan multi tafsir. Dalam alasan-alasan tersebut ada faktor kompetensi masa depan, dimana lulusan harus mampu berkomunikasi, berpikir jernih dan kritis, mampu mempertimbangkan segi moral suatu permasalahan.

Dari beberapa permasalahan tersebut di atas, pada tahun 2013 pemerintah menetapkan pemberlakuan kurikulum baru berlabel Kurikulum 2013 menggantikan kurikulum sebelumnya. Penyusunan Kurikulum 2013 adalah bagian dari melanjutkan pengembangan KBK yang telah mulai di rilis pada 2004 dengan mencakup kompetensi sikap, pengetahuan, dan keterampilan secara terpadu, sebagaimana amanat UU 20 tahun 2003 tentang Sistem Pendidikan Nasional pada penjelasan pasal 35, dimana kompetensi lulusan merupakan kualifikasi kemampuan lulusan yang mencakup sikap, pengetahuan, dan keterampilan sesuai dengan standar nasional yang telah disepakati (Chamistijatin, 2009: 32).

\section{Kesimpulan}

Pendidikan karakter merupakan usaha sadar yang terencana dan terarah melalui lingkungan pembelajaran untuk tumbuh kembangnya seluruh potensi manusia yang memiliki watak dan kepribadian baik, bermoral-berakhlak, dan berefek positif konstruktif pada alam dan masyarakat. Aspek penting pendidikan karakter dalam pembangunan karakter bangsa, dapat ditinjau secara filosofis, ideologis, dan normatif.

Kurikulum 2013 merupakan hasil review dari kurikulum sebelumnya, bertujuan untuk mempersiapkan manusia Indonesia agar memiliki kemampuan hidup sebagai 
pribadi dan warga Negara yang beriman, produktif, kreatif, inovatif, dan afektif serta mampu berkontribusi pada kehidupan masyarakat, berbangsa, bernegara, dan peradaban dunia.

Implementasi pendidikan karakter dalam kurikulum 2013, dapat dilakukan melalui proses integrasi capaian pembelajaran, mensinergikan peran lembaga pendidikan, guru manampakkan diri sebagai guru berkompeten dan diteladani. 


\section{DAFTAR PUSTAKA}

Abdul Majid, D. A. (2011). Pendidikan Karakter Perspektif Islam. Yogyakarta: Remaja Rosdakarya.

Chamistijatin. (2009). Pengembangan Kurikulum SD. Jakarta: Direktorat Jenderal Pendidikan Tinggi.

Haryanto, M. S. (2012). Konsep dan Model Pendidikan Karakter. Bandung: Remaja Rosda Karya.

Hasan, A. A. (1985). Nazariyah Al-TarbiyahFi Al-Qur'an wa-Tatbiqatuha fi Ahdi Rosulillah SAW. Qairo: Dar Al-ma'arif.

Hidayatullah, F. (2010). Pendidikan Karakter Membangun Peradaban Bangsa. Surakarta: Yuma Pustaka.

Kesuma, D. (2011). Pendidikan Karakter. Bandung: Rosdakarya.

Megawangi, R. (2007). Character Parenting Space. Bandung: Read.

Mulyasa. (2013). Pengembangan dan Implementasi Kurikulum 2013. Yogyakarta: Remaja Rosdakarya.

Muslich, M. (2011). Pendidikan Karakter Menjawab Tantangan Krisis Multidimensional. Jakarta: Bumi Aksara.

Prihatin, E. (2008). Konsep Pendidikan. Bandung: Karsa Mandiri Persada.

Sukmadinata, N. S. (2010). Pengembangan Kurikulum Teori dan Praktek. Bandung: Remaja Rosdakarya.

Suyadi. (2013). Strategi Pembelajaran Pendidikan Karakter. Bandung: Remaja Rosdakarya.

Syarbini, A. (2012). Buku Pintar Pendidikan Karakter. Jakarta: Asa-Prima Pustaka.

Syarif, A. H. (2004). Pengembangan Kurikulum. Surabaya: Bina Ilmu.

Wibowo, A. (2013). Manajemen Pendidikan Karakter di Sekolah. Yogyakarta: Pustaka Pelajar. 